ÇOMÜ Uluslararası Sosyal Bilimler Dergisi 3 (2), 169-190 , 2018

COMU International Journal of Social Sciences 3 (2), 169-190 , 2018

\title{
Türkiye'de Yabancı İşçi Çalıştırılmasının Çalışanlar ve Çalışmayanlar Üzerine Etkileri
}

Tuğçe BAYRAKTAR* ${ }^{*}$

Havva GÜLLE**

Öz

$\mathrm{Bu}$ araştırmanın amacı, yabancı işçi çalıştırılmasının çalışan kesime etkisini ve çalışan kesimin bakış açısını ve bu durumlara karşı düşüncelerini incelemektir. Bunun için çalışan kişiler ile araştırma gerçekleştirilmiştir. Araştırma modeli olarak betimsel ve ilişkisel tarama modeli tercih edilmiştir. Araştırmaya 219 kişi (75 Kadın ve 144 Erkek olmak üzere 219 birey) katılmıştır. Araştırmanın verileri Kişisel Bilgi Formu ve Yabancı İş̧ç Çalışıtırılmasına Yönelik Alg 1 Ölçeği ile toplanmıştır. Elde edilen verilerin analizinde çıkarımsal istatistikler çerçevesinde Bağımsız Örneklemler T-Testi ve ANOVA kullanılmıştır. Gerçekleștirilen analizler sonucunda elde edilen bulgular şu şekilde özetlenebilir: Çalışanların yabancı uyruklu (kaçak) işçi çalıştırmanın çalışanlar için bir risk oluşturmadığı algısının, çalışanlar ve çalışma sistemi için dezavantajlı olduğu görüşünün ve çalışanlar için tehlike oluşturduğu algısının eğitim durumuna göre anlamlı bir farklılık gösterirken; cinsiyete, medeni duruma, yaşa, meslekte çalışma süresine, bulunduğu kurumda çalışma süresine göre bir farklllık göstermediği saptanmıştır. Çalışanların yabancı uyruklu (kaçak) işçi çalıştırma ile ilgili olumlu görüş düzeylerinin, beyin göçüne etkisi olduğu görüşünün ve küresel katkısı olduğu görüşünün eğitim durumuna, cinsiyete, medeni duruma, yaşa, meslekte çalışma süresine, bulunduğu kurumda çalışma süresine göre bir farklılık göstermediği saptanmıştır

Anahtar kelimeler: Kaçak işçi, T-Testi, Anova, Faktör analizi, Yabancı işçilerin etkileri

\footnotetext{
* Yüksek Lisans öğrencisi, İstanbul Aydın Üniversitesi, Sosyal Bilimler Enstitüsü, bayraktartugce@gmail.com

(C) Sorumlu yazar/ Corresponding Author

** Yüksek Lisans öğrencisi, İstanbul Aydın Üniversitesi, Sosyal Bilimler Enstitüsü, havvagulle13@gmail.com
} 


\title{
Effects of Hiring Unregistered Foreign-Born Workers on Employees and Unemployed in Turkey
}

\begin{abstract}
The aim of this article is to examine the effect of hiring unregistered foreignborn workers on employees in Turkey, and the perceptions of those workers. Descriptive and relational survey models have been used in this research. The study was conducted with a total of 219 workers (75 female and 144 male). The data of the study were collected via a Personal Information Form and Perception Towards Hiring Unregistered Foreign-Born Employees Scale. During the analysis process of the acquired data, an Independent-Samples T-Test and ANOVA were applied in terms of deductive statistics.
\end{abstract}

The findings of the analysis can be summed up as follows: it has been found that the perception of whether hiring unregistered foreign-born employees poses a risk for workers, the perception of whether hiring unregistered foreignborn employees causes disadvantages for workers and the working system, and the perception of whether hiring unregistered foreign-born employees causes danger to workers, differ depending on educational status, while it does not differ depending on gender, marital status, age, total working duration, or working duration in an actual job.

It has been found that positive opinions among workers in relation to hiring unregistered foreign-born employees, opinions over whether hiring unregistered foreign-born employees effects a brain drain, and opinions over whether hiring unregistered foreign-born employees makes a global contribution, do not differ depending on educational status, gender, marital status, age, total working duration, or working duration in an actual job.

Keywords: Illegal worker, T-Test, Anova, Factor analysis, Effects of Foreign Workers

\section{GíRiş}

Yabancı işçi konusu tarihsel sürecine bakıldığında oldukça geriye giden bir olgudur. Fakat Türkiye'nin almış olduğu göçler incelendiğinde; 1920-1930 yılları arasında alınan Rum göçü yaşandığı, 1930-1980 yılları arasında kadar daha çok Türk kökenlilerin, 1980 sonrasında ise yabancı kökenlilerin göç ettiği gözlemlenmiştir(Deniz, T. 2014). Türkiye’ye göç konusunda en güncel durum ise Orta Doğu'da meydana gelen karışıklıklardan dolay1 alınan yoğun göçtür. Söz konusu bu karışıklıklardan dolayı Türkiye'ye başta Suriye olmak üzere birçok Ortadoğu ülkesinden göç almış ve almaya devam etmektedir. 
Yabancıların iş yaşamına girişi çoğunlukla yasal olmayan yollardan gerçekleşmektedir. Türkiye'ye gelmiş ve iş hayatına girmiş olan yabancıların önemli bir bölümü kaçak olarak çalışmaktadır. Kaçaklık ile kast edilen yalnızca güvencesizlik değil oturma, çalışma izni bulunmaksızın, resmi kuruluşların bilgisi olmadan iş gücü piyasasına katılmaktır (Lordoğlu, 2002:2).

Günümüzde tüm dünyada illegal göç konusu üzerine odaklanılmış ve caydırıcı yasal düzenlemeler getirilmektedir. Tüm bunlara rağmen illegal göç ve beraberinde gelen yabancı kaçak işçi kavramına kesin bir çözüm bulunabilmiş değildir. Küresel sermayenin dünyanın farklı yerlerinde yatırım yapması, liberal politikalar üzerine kurulu küresel düzende yabancı kaçak işçi sorununu bitirememiştir.

Hem sendikaların hem de hükümetin açıklamalarına bakarak kaçak işçiliğin Türkiye için oldukça uzun bir zamandır sorun teşkil ettiğini söyleyebiliriz. Türkiye'de halen yürürlükte olan 4817 sayılı "Yabancıların Çalışma İzinleri Hakkındaki Kanun” da yabancı işçilerin kayıt altında istihdam edilmesi hususundaki bürokratik süreçleri hafifletilirken, kaçak işçiliği önlemenin çözümü verilen cezaları artırmakta aranmaktadır. Fakat yapılan denetlemelerin yeterli düzeyde olmamasından dolayı işverenlerin bir kısmı ceza riskini göze alıp, işverenin kârını maksimize edip işçi maliyetini düşüren kaçak çalışan işçileri tercih etmektedirler. Bu da iş piyasasında haksız rekabeti ortaya çıkarmaktadır.

Ekonomik bir sistemde yabancı (kaçak) işçi çalıştırılmasının etkisi giderek artarak kayıt dışı işgücü piyasasını oluşturup çeşitli vergi yüklerini doğuracaktır. Gelir adaletinin yıpranması sosyal yapının olumsuz etkilenmesine neden olacaktır.

Yapılan bu çalışmanın amacı Türkiye ekonomisini doğrudan veya dolaylı olarak etkileyen yabancı işçi çalıştırılmasının çalışan ve çalışmayan kesime etkisini, işverenlerin yabancı işçi tercihine çalışan ve çalışmayan kesimin bakış açısını ve bu durumlara karşı düşüncelerini saptamaktır. Yapılan bu çalışmada sosyal bilimlerdeki araştırma çeşitlerinden saha araştırması kullanılıp tarama yöntemi yapılmış ve veri toplama aracı olarak nicel araştırma yöntemi olan anket uygulanmıştır. 219 kişiden oluşan örneklem grubuna yabancı (kaçak) işçi çalıştırılmasına bakış açısını saptamak amacıyla hazırladığımız 26 maddelik ankette, ilk 6 soruda demografik özelliklere yer verilmiş olup geri kalan 20 soru konuya yönelik olarak değerlendirme soruları kullanılmıştır. Değerlendirme soruları için likert tipi derecelendirme kullanılmıştır. Literatüre baktığımızda yapılan bu çalışmanın yapılmış bir benzeri olmadığı, alanında bu tarzda yapılan ilk inceleme çalışması olacaktır. $\mathrm{Bu}$ çalışmanın bundan sonraki çalışmalarda yabancı (kaçak) işçi konusunda araştırma yapmak isteyen kişilere yol gösterici olacağı düşünülmektedir.

\section{YABANCI VE KAÇAK IŞÇILİK}

Türkiye'ye gelmiş ve iş hayatına girmiş olan yabancıların önemli bir bölümü kaçak biçimde çalışmaktadır. Kaçaklık ile kast edilen yalnızca güvencesizlik değil oturma, çalışma izni bulunmaksızın, resmi kuruluşların bilgisi olmadan işgücü piyasasına 
katılmaktır. Çalışma izni bulunan yabancıların istihdam oranına bakıldığı zaman küçük bir orana sahip olduğu görülmektedir (Lordoğlu, 2002:2).

Yabancı kavramını literatürde incelediğimizde karşımıza en yaygın olan kullanım şekli "ülkesinde yaşamakta olduğu devlete vatandaşlıkla bağlı bulunmayan kişiler" olarak çıkmaktadır (Aydınoğlu, 2006). Bu ifade de görülebileceği gibi yabancı kavramı hukuksal bir temele yerleştirilerek aidiyet açısından etnisite, dil, kültür, din, soy, milliyet birlikteliğinin yerine uyruk esası getirilerek literatüre geçmiştir. Vatandaş ya da yurttaş sıfatlarını taşımakta olan bireylerin sahip oldukları kanuni haklar ile yabancı statüsündekilerin hakları birbirlerinden oldukça farklıdır. Vatandaşlar ülkelerindeki kanunlar tarafından koruma altında tutulurlarken yabancılarsa yalnızca yaşadıkları ülkede kendilerine tanınan haklar ölçüsünde olanaklardan faydalanabilmektedirler.

Kaçak işçilik ile ilgili bir diğer önemli konu ise "göç" kavramıdır. Göç kavramının birbirinden bağımsız olan ve çok boyutlu değişkenler taşımaktadır. Genellikle toplumdaki politik, finansal, kültürel, sosyal yapıyla yakinen alakalı bir olgu olan göç, bahsedilen çok boyutlu özelliği sebebiyle başta hukukçu, sosyolog ve antropologlar olmak üzere toplumdaki birçok kesimin dikkatini çekmektedir.

Göç kavramı iki başlıkta incelenebilir. Bunlar; yasal olmayan ve yasal olan şeklindedir. Yasa dışı göç temelde ülkelerin kendi sınırlarına içerisine girişlerde belirlemiş oldukları kurallara uyulmaksızın yapılan giriş ihlallerini ifade ederken yasal göç ise tamamen tersi bir yapıyı ifade eder.

Kanuni olmayan göç ve kanuni göç olguları, çalışma yaşamında yasal biçimde ülkemize girerek yasal olarak hayatını sürdürmekte olan ancak kaçak bir biçimde çalışan, kanuni yollarla girmiş olup vize süresi bitmiş olan kaçak çalışan ve kanun dışı metotlarla ülkeye girip yine kanun dışı metotlarla çalışan işçilerle alakalı sorunları doğurmuştur (Koç, 2000: 2).

Yabancı kaçak işçileri başka ülkelerde bulunmakta olup var olan mevzuatlara göre çalışma ve oturma izni bulunmadığ 1 halde herhangi bir hizmet akdi bulunmaksızın enformel ve formel sektörlerde iş gören kişiler olarak ifade etmek mümkündür (Duymaz, 1995: 9).

Yabancı işliğin ortaya çıkış durumuna bakıldığında hem hedef hem kaynak ülkeleri ilgilendiren iki boyutlu bir olgu olduğu görülmektedir. Ortaya çıkma biçimi ülkelere göre değişiklik göstermekte olan yabancı işçilikte çıkış sebepler sadece nitel biçimde gruplandırılabilmektedir. Dini, coğrafi, demografik temelde olabilen bu maddeler konjonktürel olarak meydana gelen öngörülmez nedenlerde içerebilmektedir.

İş yaşamı bakımından ise formel iş gücündeki piyasalarının yapıları işsizlik oranlarında yükselmeleri işsizlik sigortasıyla beraber belli bir düzeyde karşılayabilmektedir. Fakat resmi olmayan ekonomilerin yaygın olması neticesinde gelişmekte olan ülkelerde bulunan yüksek oranda işsizlik resmi olmayan istihdam imkânlarıyla telafi edilebilmektedir. Bu 
bakımdan 1990'lardan itibaren çalışma amacıyla Türkiye'ye gelmiş olan yabancıların hâlihazırdaki yüksek oranda işsizliği daha da arttırması ile resmi olmayan piyasalar içerisinde ücret seviyesini aşağı çekerek çalıştıkları göze çarpmaktadır.

Günümüzde tüm dünyada bilhassa göç alan ülkeler illegal göç konusu üzerine odaklanarak caydırıcı yasal düzenlemeler geliştirmiştir. Yine de illegal göç ve beraberinde gelen yabancı kaçak işçi kavramına yönelik bir çözüm bulunabilmiş değildir. Ne küresel sermayesinin dünyanın farklı yerlerinde yatırım yapması, ne de vasıfsız iş gücünün çalışma koşulları ve kazancına yönelik verdiği tavizler liberal politikalar üzerine kurulu küresel düzende yabancı kaçak işçi sorununu bitirememiştir. Her ne kadar esnek bırakılan hukuki kaideler bahsi geçen sorunun büyümesini bir raddeye kadar engellemiş olsa da, sıkıntının sistematik bir duruma gelmesini durduramamıştır.

Türkiye'de hem sendikalar hem de hükümet tarafından yapılan açıklamalarına baktığımızda kaçak işçiliğin Türkiye için uzun süredir bir sorun olarak algılandığını söyleyebilmekteyiz. Kaçak işçilik ve yabancı kaçak işçilik arasındaki fark bu bağlamda oldukça azdır. Bu konuların her ikisi de "ișgücü piyasalarının düzenlenmesi" algısıyla işlenmektedir. Ecevit Hükümeti tarafında hazırlanan "Yabancıların Çalışma İzinleri Hakkındaki Kanun" yabancıların Türkiye'de istihdam edilmesi konusunda bürokratik süreçleri hafifletirken, sorunun çözümü verilen cezaları arttırarak aranmaktadır. Bahsi geçen Kanunun bir başka hedefi ise işçilerin kayıtlara geçme sürecini başlatmaktır. Türkiye'de çalışanların ancak yarısının kayıtlı olduğu göz önünde bulundurulursa, kayıtlı olarak istihdam edilen yabancı sayısının artacağı olasılığı düşük kalmaktadır (Lordoğlu, 2002:7).

Yabancıların Türkiye'de çalışmasına yönelik doğrudan ya da dolaylı düzenlemeler 70 civarında yasa, tüzük, bakanlar kurulu kararı, yönetmelik ve talimatnamede yer almaktadır. Ülkemizde bir aydan uzun süreyle vakit geçirecek olan yabancılar bu dönem sona ermeden önce ikamet tezkeresi almak için gerekli işlemleri yapmak üzere yetkili emniyet makamlarına şahsen ya da aracılar vasıtasıyla başvurmakla görevlidir. Çalışma amacıyla ülkeye gelen yabancılar buraya ulaştıkları tarihten sonra bir ay içinde ve her koşulda çalışmaya başlamadan önce ikamet tezkeresi almak zorundadır (5683 Sayılı YISHK, Resmi Gazete: 7564,1950).

Tekrarlanmaları durumunda yukarıda sayılan idari para cezaları bir kat arttrrılarak uygulanır. İşveren aynı zamanda yakalanan yabancının vizesiz kaldığı her gün için ödeyeceği cezalar ile yurt dışına çıkarılma masraflarından da sorumludur (Tezel, 2013:4).

Gelir farklılıkları globalleşme ile birlikte bir yandan artarken bir yandan da daha görünür hale gelmiştir. "Özgür" dolaşımın araçları muhtemelen bilgiyi saklamanın her geçen gün daha zor hale gelmesiyle temin edilebilmiştir. Hem zenginleşme hem de fakirleşme eğilimi gösterenlerin durumun farkında olarak ilerledikleri dünya düzeni için farklılıklar kadar onların bilincinde olmak da eskiye nazaran daha büyük bir üstünlük sağlamaktadır. 
Ortaya çıkan gelir farklılığı, fakirleşme eğiliminde olan ülkeler ve vatandaşları için büyük bir sıkıntı haline gelmektedir. Kültürel değerler maddi açıdan karşılık bulmadıkları sürece önemlerini yitirmekte, bahsi geçen ülkelerde yaşayanların başta satın alma kapasiteleri olmak üzere tüm değerleri süratle zarar görmektedir (Lordoğlu, 2004: 8).

\section{VERİ VE YÖNTEM}

Araştırmanın bu bölümünde öncelikle çalışmanın yöntemi ve çalışma grubundan söz edilerek veri toplama araçları ile ilgili bilgiler verilmiştir. Daha sonra veri analizinde kullanılan istatistiksel yöntemler açıklanmıştır.

\subsection{Araştırmanın Amacı ve Modeli}

$\mathrm{Bu}$ araştırma yabancı işçi çalıştırılmasının çalışan kesime etkisini ve KOBİ'lerin veya işverenlerin yabancı işçi tercihine çalışan kesimin bakış açısını ve bu durumlara karşı düşüncelerini saptamak amacı ile "tarama modeli" olarak tasarlanmıştır. Tarama modelleri, geçmişte ya da halen var olan bir durumu var olduğu şekilde betimlemeyi amaçlayan araştırma yaklaşımlarıdır. Araştırmaya konu olan olay, birey ya da nesne, kendi koşulları içinde ve olduğu gibi tanımlanmaya çalışılır ( Karasar, 2009).

\subsection{Araştırmanın Evreni ve Örneklemi}

Araştırmanın örneklemini, İstanbul ilinde çalışmakta olan 219 birey oluşturmaktadır. Bu çalışmanın evreni Türkiye' deki çalışan ve çalışmayan kesimi kapsamaktadır. Bu çalışma evreni çok geni olduğu için daraltılarak en aza indirilmiş olup, 219 kişiye uygulanmıştır. 219 kişilik çalışma evreni; 206 kişiden oluşan örneklem tanınmış bir bankanın 60 kadar çalışanına yüz yüze anket uygulanarak, Esenler ilçesinde bulunan bir kısım esnafın 50 kadar çalışanına yüz yüze anket uygulanarak, tanınmış bir üniversitede eğitim alan 40 kadar öğrenciye yüz yüze anket uygulanarak ve sosyal medya aracılığ 1 ile online yapılan çalışmada 69 kişiye anket uygulanarak oluşmuştur.

\subsection{Demografik Bilgilerin Dağılımı}

Araştırmaya katılan çalışanların demografik bilgilerinin dağılımı Tablo1'de sunulmuştur. 
Tablo 1. Yabancı İşçi Alımlarının Çalışanlar ve Çalışmayanlar Üzerindeki Etkisi Çalışmasının Demografik Bilgilerinin Dağılımları ve Yüzdeleri

\begin{tabular}{|c|c|c|c|}
\hline & & $\mathbf{n}$ & $\%$ \\
\hline \multirow{2}{*}{ Cinsiyet } & Kadın & 75 & 34 \\
\hline & Erkek & 144 & 66 \\
\hline \multirow{2}{*}{ Medeni Durum } & Bekâr & 155 & 71 \\
\hline & Evli & 64 & 29 \\
\hline \multirow{3}{*}{ Yaş } & $18-25$ & 81 & 37 \\
\hline & $25-35$ & 92 & 42 \\
\hline & 35 yaş ve üzeri & 46 & 21 \\
\hline \multirow{4}{*}{ Eğitim Durumu } & Lise & 68 & 31 \\
\hline & Ön lisans & 50 & 23 \\
\hline & Lisans & 75 & 34 \\
\hline & Yüksek Lisans & 26 & 12 \\
\hline \multirow{3}{*}{ Meslekte Çalışma Süresi } & $0-5$ yıl arası & 77 & 35 \\
\hline & $5-10$ yil arası & 70 & 32 \\
\hline & 10 yıl ve üzeri & 72 & 33 \\
\hline \multirow{3}{*}{ Şuan ki Kurumda Çalışma Süresi } & $0-5$ yıl arası & 116 & 53 \\
\hline & 5 yil ve üzeri & 103 & 47 \\
\hline & Toplam & 219 & 100 \\
\hline
\end{tabular}

Araştırmaya katılan kişilerin \%34’i (75 kişi) kadın ve \%66’i (144 kişi) erkektir. Kişilerin \%71'i (155 kişi) bekâr ve \%29'i (64 kişi) evlidir. Kişilerin \%37’i (81 kişi) 18-25 ve \%42’i (92 kişi) $25-35$ ve \%21'i (46 kişi) 35 yaş ve üzeridir. \%31'i (68 kişi) lise mezunu olan kişilerin, \%23'i (50 kişi) ön lisans, \%34'i (75 kişi) lisans ve \%12'i (26 kişi) yüksek lisans mezunudur. Kişilerin meslek hayatında geçirdikleri süre sorulduğunda \%35'i (77 kişi) 0-5 y1l arası ve \%32'i (70 kişi) 5-10 y1l arası ve \%33'ü (72 kişi) 10 yıl ve üzeri süre ile çalışmakta olduklarını belirtmiştir. Kişilerin \%53'i (116 kişi) 0-5 yıl arası ve \%47’i (103 kişi) 5 yıl ve üzeri süre ile şu anki kurumda çalışmaya devam etmektedir.

\subsection{Veri Toplama Araçları}

Örneklemi oluşturan 219 kişiden oluşan çalışan ve çalışmayan kesimin yabancı uyruklu işçi çalıştırılmasına bakış açısını saptamak amacıyla hazırlanmış 26 soruluk ankette, ilk 6 soruda kişisel bilgilere yer verilmiş olup geri kalan 20 soruda 5'li likert ölçeği kullanılmıştır.

Anketin ilk bölümünde cinsiyet, yaş aralığı, eğitim durumu, medeni hali, mesleki çalışma süresi ve şuan ki kurumunda çalışma süresini içeren kişisel bilgiler yer almaktadır. Anketin ikinci bölümünde yabancı uyruklu işçi çalıştırılmasının etkisini ölçmek amacıyla 20 değerlendirme sorusu hazırlanmıştır. Her soru için 1: kesinlikle katılmıyorum, 5: kesinlikle katılıyorum şeklinde 5'li likert tipi derecelemeye göre değerlendirilerek elde 
edilmektedir. Anketin geçerlilik ve güvenilirliği çalışma içerisinde gerçekleştirilmiştir.

\subsection{Araştırmanın Hipotezleri}

Çalışmaya başlamadan önce belirlenmiş olan çalışma hipotezleri aşağıdaki gibidir;

H1: Çalışanlar tarafından yabancı uyruklu (kaçak) işçi çalıştırılması, çalışan kesim için bir risk olarak algılanmaktadır.

H2: Çalışanlar tarafindan yabancı uyruklu (kaçak) işçi çalıştırılması, çalışan kesim için dezavantajlı görülmektedir.

H3: Çalışanlar tarafından yabancı uyruklu (kaçak) işçi çalıştırılması, çalışan kesim için tehlike olarak görülmektedir.

H4: Çalışanlar yabancı uyruklu (kaçak) işçi çalıştırma ile ilgili olumlu görüşlere sahip değillerdir.

H5: Çalışanlar tarafından yabancı uyruklu (kaçak) işçi çalıştırılması, beyin göçüne neden olmaktadir.

\subsection{Verilerin Analizi}

Araştırmada elde edilen veriler IBM SPSS 21 paket programı aracılığıyla istatistiki test ve analizler uygulanarak çözümlenmiştir. Çözümlenen veriler söz konusu istatistiksel test ve analizlerin bilimsel yaklaşımları doğrultusunda değerlendirilerek raporlanmıştır. Araştırmada incelenen yabancı işçi çalıştırılmasının çalışanlardaki alg1 ve görüşlerinin demografik değişkenlere bağlı olarak değişimini ortaya çıkaracak bir desen içinde ele alınmıştır.

Bağımsız Örnekler T-Testi: İki aritmetik ortalama arasındaki farkın manidarlığını test etmede kullanılan parametrik bir analizdir.

Tek Yönlü Varyans analizi: İki ya da daha fazla ortalama arasında fark olup olmadığı ile ilgili önermeyi test etmek amacıyla kullanılan parametrik bir testtir.

Korelasyon analizi: İki değişken arasında doğrusal bir ilişki olup olmadığını, varsa bu ilişkinin yönünü ve şiddetinin ne olduğunu belirlemek için kullanılan bir istatistiksel yöntemdir.

\subsection{Veri Toplama Araçlarının Geçerliliği ve Güvenirliği}

Bu araştırmada 20 maddeden oluşan ölçeğin iç tutarlılığı güvenilirlik düzeyini test etmek amacıyla hesaplanmıştır. Güvenirlik analizi, ölçmede kullanılan araçların güvenilirliğini değerlendirmek amacıyla geliştirilmiş bir yöntemdir. Cronbach’s Alpha Katsayısının 
bulunabileceği aralıklar ve değerlendirme kriteri şu şekildedir; $0,00 \leq \alpha<0,40$ ise ölçek güvenilir değildir. $0,40 \leq \alpha<0,60$ ise ölçek düşük güvenilirliktedir. $0,60 \leq \alpha<0,80$ ise ölçek oldukça güvenilirdir. $0,80 \leq \alpha<1,00$ ise ölçek yüksek derecede güvenilir bir ölçektir. 20 soruluk likert yapılı ölçek maddelerinin güvenirlik değeri Tablo 2.'de sunulmuştur.

İç tutarlılık kat sayısı (Cronbach’s Alpha) = 0,666 olup, buna göre ölçeğin oldukça güvenilir olduğu tespit edilmiştir. Madde silinirse Cronbach's Alpha değeri sütunu, değerin ait olduğu sorunun silinmesi durumunda alfa iç tutarlılık kat sayısının hangi değeri alacağını ifade etmektedir. Herhangi bir madde çıkarıldığı durumda alfa seviyesi manidar bir artış göstermeyecektir. Mevcut iç tutarlılık kat sayısına göre oldukça seviyede güvenilir olması sebebi ile herhangi bir soru maddesinin ölçek dışında bırakılması gerekliliği bulunmamaktadır.

\subsection{Faktör Analizi}

Bu çalışmada 20 maddeli ölçeğin yapı geçerliliği açıklayıcı faktör analizi ile ölçülmüştür. Faktör analizinde öz değeri 1'den büyük olan gruplar faktör olarak sıralanır. Uygulanan ölçek maddelerinin oluşturdukları faktörlerin, toplam varyansın ne kadarını açıkladığı ve soruların bir ölçek olma özelliği için gerekli olan geçerlilik ölçütlerini ne kadar sağladığını incelemek amacıyla bu yöntem tercih edilmiş ve sonuçları aşağıda verilmiştir.

Ölçeğin faktör analizine uygunluğunu değerlendirme kriteri olan KMO and Bartlett's Test'i sonucu elde edilen KMO değeri $=0,802>0,50$ olup, ölçeğin faktör analizi için uygunluğu belirlenmiştir. Bartlett's Test of Sphericity'e ait Sig. $=0,000$ değeri anlamlı olup, ölçek soruları arasında yüksek korelasyon olduğu gözlenmektedir.

Tabloda yer alan sonuçlara göre özdeğer istatistiği 1'den büyük olan gruplar birer faktör olarak sınıflandırılabilir. Buna göre altı faktör sınıfı söz konusudur. Bu faktör grupları toplam varyansın \%59,2'lik kısmını açıklamaktadır.

Tablodaki Döndürülmüş Bileşen Matrisi (Rotated Component Matrix) tablosu içerisinde ölçek soruları altı faktör altında toplanmaktadır ve faktör yükleri belirtilmiştir. Varimax döndürmesi sonucunda gözlemlenen Faktör 1'in 4 maddeden oluştuğu, Faktör 2'nin 4 maddeden oluştuğu; Faktör 3 'ün 4 maddeden oluştuğu; Faktör 4 'ün 3 maddeden oluştuğu: Faktör 5'in 3 maddeden oluştuğu; Faktör 6'nın 2 maddeden oluştuğu görülmektedir. Faktörler ölçeklerde yer alan boyutlara aşağıdaki şekilde uymaktadır:

Faktör 1: Yabancı Uyruklu (Kaçak) İşçi Çalıştırmanın Risk Olarak Algılanmaması

Faktör 2: Yabancı Uyruklu (Kaçak) İşçi Çalıştırmanın Dezavantajlı Görülmesi

Faktör 3: Yabancı Uyruklu (Kaçak) İşçi Çalıştırmanın Tehlike Olarak Görülmesi

Faktör 4: Yabancı Uyruklu (Kaçak) İşçi Çalıştırma İle İlgili Olumlu Görüşler

Faktör 5: Yabancı Uyruklu (Kaçak) İşçi Çalıştırmanın Beyin Göçüne Etkisi

Faktör 6: Yabancı Uyruklu (Kaçak) İşçi Çalıştırmanın Küresel Katkısı 


\section{Tablo 2. Yabancı Uyruklu (Kaçak) İşçi Alımlarının Çalışanlar ve Çalışmayanlar Üzerindeki Etkisinin Madde İstatistikleri}

\begin{tabular}{|c|c|c|}
\hline & $\begin{array}{l}\text { Cronbach's Alpha } \\
\text { (Eğer Madde Silinirse) }\end{array}$ & $\begin{array}{l}\text { Cronbach's } \\
\text { Alpha }\end{array}$ \\
\hline $\begin{array}{l}\text { Yabancı Uyruklu (Kaçak) İş̧̧i çalıştırılması işim açısından bir tehlike } \\
\text { oluşturmuyor. }\end{array}$ & ,657 & \multirow{20}{*}{ 666, } \\
\hline $\begin{array}{l}\text { Yabancı Uyruklu (Kaçak) İşçilerin çalışıor olması benim iş bulmama } \\
\text { engel olmamaktadır. }\end{array}$ & ,651 & \\
\hline $\begin{array}{l}\text { Yabancı uyruklu ucuz işçi hak ettiğim ücretin düşük olmasına sebep } \\
\text { oluyor. }\end{array}$ & ,651 & \\
\hline $\begin{array}{l}\text { Yabancı iş gücünün uzmanlık gerektiren birimlerde çalıştırılması ülke- } \\
\text { mize katkı sağladığını düşünüyorum. }\end{array}$ & ,656 & \\
\hline $\begin{array}{l}\text { Yabancı Uyruklu (Kaçak) İşçi çalıştırılmasında kayıt dışı olmalarının } \\
\text { önüne geçilmesi için daha etkili kuralların olması gerektiğini düşünü- } \\
\text { yorum. }\end{array}$ & 646 & \\
\hline $\begin{array}{l}\text { Yabancı Uyruklu (Kaçak) İşçi çalıştırılması küreselleşmenin boyutunu } \\
\text { hızlandırır. }\end{array}$ & ,653 & \\
\hline $\begin{array}{l}\text { Yabancı Uyruklu (Kaçak) İşçi iş bulma ve işin devamlılığı konusunda } \\
\text { tehlike arz etmiyor. }\end{array}$ & ,655 & \\
\hline $\begin{array}{l}\text { Ülkeme Yabancı Uyruklu (Kaçak) İşçinin gelmesi ülkemizdeki yerel iş } \\
\text { gücünün yurt dışına çıkmasına neden olur. }\end{array}$ & ,661 & \\
\hline $\begin{array}{l}\text { Şrketlerin iş sahasına yurt dışından ucuz iş gücü getirmesini doğru } \\
\text { buluyorum. }\end{array}$ & ,663 & \\
\hline $\begin{array}{l}\text { Türkiye’de Yabancı Uyruklu (Kaçak) İşçi çalıștırılması iş ve iş̧̧i güven- } \\
\text { liğini etkilemez. }\end{array}$ & ,667 & \\
\hline $\begin{array}{l}\text { Türkiye’deki sanayicilerin yurt dışından Yabancı Uyruklu (Kaçak) İşçi } \\
\text { getirmelerini doğru buluyorum. }\end{array}$ & ,667 & \\
\hline $\begin{array}{l}\text { Yabancı uyruklu ucuz işçilerden dolayı işimi kaybetmekten korkuyo- } \\
\text { rum. }\end{array}$ & ,653 & \\
\hline $\begin{array}{l}\text { Yabanc1 uyruklu ucuz işçi yüzünden eğitimli genç nüfusun işsizlikle } \\
\text { mücadele ettiğini düşünüyorum. }\end{array}$ & ,643 & \\
\hline $\begin{array}{l}\text { Orta Doğu'daki savaşın sürmesi ülkemizde işsizliği arttıracağını düşü- } \\
\text { nüyorum. }\end{array}$ & 648 & \\
\hline $\begin{array}{l}\text { İşverenlerin kayıt dışı Yabancı Uyruklu (Kaçak) İşçi çalıştırması tecrü- } \\
\text { besiz eleman alımında dezavantajdır. }\end{array}$ & ,649 & \\
\hline $\begin{array}{l}\text { İşverenlerin Yabancı Uyruklu (Kaçak) İşçi çalıştırması sektörde yerli } \\
\text { işçi çalıştırmaya engel değildir. }\end{array}$ & ,672 & \\
\hline $\begin{array}{l}\text { Yabancı Uyruklu (Kaçak) İşçi sayısının sınırlandırılmasını doğru bu- } \\
\text { luyorum. }\end{array}$ & ,645 & \\
\hline $\begin{array}{l}\text { Artan Yabancı Uyruklu (Kaçak) İşçi sayısı ile beraber şirketlerin taşe- } \\
\text { ronlaşmasını da artıracağını düşünüyorum. }\end{array}$ & ,650 & \\
\hline $\begin{array}{l}\text { Teknik bilgi gerektiren konularda yabancı iş gücü sağlanması ülkemde- } \\
\text { ki nitelikli iş gücünün beyin göçüne neden olmaktadır. }\end{array}$ & ,645 & \\
\hline $\begin{array}{l}\text { Yabancı Uyruklu (Kaçak) İş̧i fazlalığının bölgedeki sosyal yaşamı } \\
\text { olumsuz etkilediğini düşünüyorum. }\end{array}$ & ,647 & \\
\hline
\end{tabular}




\begin{tabular}{|c|c|c|c|c|c|c|c|}
\hline \multicolumn{7}{|l|}{ Tablo 3. Döndürülmüş Matris } & \multirow{3}{*}{$\begin{array}{l}\text { Açıllanan } \\
\text { Toplam } \\
\text { Varyans } \\
\begin{array}{c}\text { Kümüla- } \\
\text { tiv \% }\end{array}\end{array}$} \\
\hline & \multicolumn{6}{|c|}{ Faktör } & \\
\hline & 1 & 2 & 3 & 4 & 5 & 6 & \\
\hline $\begin{array}{l}\text { Yabancı Uyruklu (Kaçak) İşçilerin çalışyor olması benim iş } \\
\text { bulmama engel olmamaktadır. }\end{array}$ & 0,807 & & & & & & \\
\hline $\begin{array}{l}\text { Yabancı Uyruklu (Kaçak) İşçi çalıştırılması işim açısından bir } \\
\text { tehlike oluşturmuyor. }\end{array}$ & 0,770 & & & & & & \\
\hline $\begin{array}{l}\text { Yabancı Uyruklu (Kaçak) İşçi iş bulma ve işin devamlılığı } \\
\text { konusunda tehlike arz etmiyor. }\end{array}$ & 0,691 & & & & & & 11,688 \\
\hline $\begin{array}{l}\text { İşverenlerin Yabancı Uyruklu (Kaçak) İşçi çalıştırması } \\
\text { sektörde yerli işçi çalıștırmaya engel değildir. }\end{array}$ & 0,468 & & & & & & \\
\hline $\begin{array}{l}\text { İşverenlerin kayıt dışı Yabancı Uyruklu (Kaçak) İşçi } \\
\text { çalıştırması tecrübesiz eleman alımında dezavantajdır. }\end{array}$ & & 0,772 & & & & & \\
\hline $\begin{array}{l}\text { Artan Yabancı Uyruklu (Kaçak) İşçi sayısı ile beraber şirketle- } \\
\text { rin taşeronlaşmasını da artıracağını düşünüyorum. }\end{array}$ & & 0,652 & & & & & \\
\hline $\begin{array}{l}\text { Yabancı Uyruklu (Kaçak) İşçi fazlalığının bölgedeki sosyal } \\
\text { yaşamı olumsuz etkilediğini düşünüyorum. }\end{array}$ & & 0,581 & & & & & 23,324 \\
\hline $\begin{array}{l}\text { Yabancı Uyruklu (Kaçak) İşçi sayısının sınırlandırılmasını } \\
\text { doğru buluyorum. }\end{array}$ & & 0,553 & & & & & \\
\hline $\begin{array}{l}\text { Yabancı uyruklu ucuz işçilerden dolayı işimi kaybetmekten } \\
\text { korkuyorum. }\end{array}$ & & & 0,741 & & & & \\
\hline $\begin{array}{l}\text { Yabancı uyruklu ucuz işçi yüzünden eğitimli genç nüfusun } \\
\text { işsizlikle mücadele ettiğini düşünüyorum. }\end{array}$ & & & 0,690 & & & & \\
\hline $\begin{array}{l}\text { Orta Doğu'daki savaşın sürmesi ülkemizde işsizliği arttıraca- } \\
\text { ğını düşünüyorum. }\end{array}$ & & & 0,636 & & & & 34,467 \\
\hline $\begin{array}{l}\text { Yabancı Uyruklu (Kaçak) İșçi çalıștırılmasında kayıt dışı } \\
\text { olmalarının önüne geçilmesi için daha etkili kuralların olması } \\
\text { gerektiğini düşünüyorum. }\end{array}$ & & & 0,432 & & & & \\
\hline $\begin{array}{l}\text { Şirketlerin iş sahasına yurt dışından ucuz iş gücü getirmesini } \\
\text { doğru buluyorum. }\end{array}$ & & & & & & & \\
\hline $\begin{array}{l}\text { Türkiye’de Yabancı Uyruklu (Kaçak) İşçi çalıştırılması iş ve işçi } \\
\text { güvenliğini etkilemez. }\end{array}$ & & & & 0,679 & & & 43,816 \\
\hline $\begin{array}{l}\text { Türkiye’deki sanayicilerin yurt dışından Yabancı Uyruklu } \\
\text { (Kaçak) İşçi getirmelerini doğru buluyorum. }\end{array}$ & & & & 0,628 & & & \\
\hline $\begin{array}{l}\text { Ülkeme Yabancı Uyruklu (Kaçak) İşçinin gelmesi ülkemizdeki } \\
\text { yerel iş gücünün yurt dışına çıkmasına neden olur. }\end{array}$ & & & & & 0,831 & & \\
\hline $\begin{array}{l}\text { Teknik bilgi gerektiren konularda yabancı iş gücü sağlanması } \\
\text { ülkemdeki nitelikli iş gücünün beyin göçüne neden olmak- } \\
\text { tadır. }\end{array}$ & & & & & 0,524 & & 51,783 \\
\hline $\begin{array}{l}\text { Yabancı uyruklu ucuz işçi hak ettiğim ücretin düşük olmasına } \\
\text { sebep oluyor. }\end{array}$ & & & & & 0,485 & & \\
\hline $\begin{array}{l}\text { Yabancı Uyruklu (Kaçak) İşçi çalıştırılması küreselleşmenin } \\
\text { boyutunu hızlandırır. }\end{array}$ & & & & & & 0,716 & 59234 \\
\hline $\begin{array}{l}\text { Yabanc1 iş gücünün uzmanlık gerektiren birimlerde çalıştırıl- } \\
\text { ması ülkemize katkı sağladığını düşünüyorum. }\end{array}$ & & & & & & 0,615 & 59,234 \\
\hline $\begin{array}{l}\text { Method: Temel Bileșenler Analizi. } \\
\text { Rotasyon Methodu: Varimax } \\
8 \text { İterasyonda Tamamlandı } \\
\text { Kaiser-Meyer-Olkin Measure of Sampling Adequacy. } \\
\text { Bartlett's Test of Sphericity }\end{array}$ & & & & & & & $\begin{array}{l}0,802 \\
0,000\end{array}$ \\
\hline
\end{tabular}




\section{BULGULAR}

\section{1. Çalışan Kesimin Yabancı Uyruklu (Kaçak) İşçi Çalıştırma İle İlgili Görüşleri}

Araştırmaya katılan kişilerin yabancı uyruklu kaçak işçi çalıştırılması ile ilgili genel görüşlerine ilişkin özet istatistikler Tablo 4'te sunulmuştur.

\section{Tablo 4. Çalışan Bireylerin Yabancı Uyruklu (Kaçak) İşçi Çalıştırma İle İlgili Görüşleri}

\begin{tabular}{lcccc}
\hline & Ort. & $\begin{array}{c}\text { Std. } \\
\text { Sapma }\end{array}$ & Min. & Maks. \\
\hline $\begin{array}{l}\text { Yabancı Uyruklu (Kaçak) İşçi Çalıştırmanın Risk Olarak } \\
\text { Algılanmaması }\end{array}$ & 2,73 & 1,02 & 1 & 5 \\
\hline $\begin{array}{l}\text { Yabancı Uyruklu (Kaçak) İşçi Çalıştırmanın Dezavantajlı } \\
\text { Görülmesi }\end{array}$ & 3,72 & 0,91 & 1 & 5 \\
\hline $\begin{array}{l}\text { Yabancı Uyruklu (Kaçak) İşçi Çalıştırmanın Tehlike Ola- } \\
\text { rak Görülmesi }\end{array}$ & 3,6 & 0,91 & 1 & 5 \\
\hline $\begin{array}{l}\text { Yabancı Uyruklu (Kaçak) İşçi Çalıştırma İle İlgili Olumlu } \\
\text { Görüşler }\end{array}$ & 2,34 & 1 & 1 & 5 \\
\hline $\begin{array}{l}\text { Yabancı Uyruklu (Kaçak) İşçi Çalıştırmanın Beyin Göçü- } \\
\text { ne Etkisi }\end{array}$ & 3,44 & 0,95 & 1 & 5 \\
\hline $\begin{array}{l}\text { Yabancı Uyruklu (Kaçak) İşçi Çalıştırmanın Küresel Kat- } \\
\text { kısı }\end{array}$ & 3,15 & 1,01 & 1 & 5 \\
\hline
\end{tabular}

Kişilerin genel görüşü incelendiğinde ortalamalara göre;

Çalışanların genel olarak yabancı uyruklu (kaçak) işçi çalıştırılmasının, çalışanlar için bir risk oluşturduğu görüşüne katılmakta kararsız kaldıkları görülmektedir (ort.=2,73).

Çalışanların genel olarak yabancı uyruklu (kaçak) işçi çalıştırılmasının, çalışanlar için dezavantajlı görülmesi olduğu görüşüne katıldıkları görülmektedir (ort.=3,72).

Çalışanların genel olarak yabancı uyruklu (kaçak) işçi çalıştırılmasının, çalışanlar için tehlike oluşturduğu görüşüne katıldıkları görülmektedir (ort.=3,60).

Çalışanların genel olarak yabancı uyruklu (kaçak) işçi çalıştırma ile ilgili olumlu görüşlere katılmadıkları görülmektedir (ort. $=2,34$ ).

Çalışanların genel olarak yabancı uyruklu (kaçak) işçi çalıştırmanın beyin göçüne etkisi olduğu görüşüne katıldıkları görülmektedir (ort.=3,44).

Çalışanların genel olarak yabancı uyruklu (kaçak) işçi çalıştırmanın küresel katkısı olduğu görüşüne katılmakta kararsız kaldıkları görülmektedir (ort.=3,15). 


\section{2. Çalışan Kesimin Yabancı Uyruklu (Kaçak) İşçi Çalıştırma İle İlgili Görüşlerinin Çeşitli Değişkenlere Göre İncelenmesi}

Araştırmaya katılan çalışan bireylerin yabancı uyruklu (kaçak) işçi çalıştırılmasına yönelik görüşlerinin, çeşitli değişkenlere göre istatistiksel olarak farklılık gösterip göstermediğini test etmek için tek yönlü varyans analizi ile bağımsız örnekler t-testi yapılmış ve analiz sonuçları bu bölümde sunulmuştur.

Tablo 5. Yabancı Uyruklu (Kaçak) İşçi Çalıştırmasına İlişkin Çalışan Görüşlerinin Cinsiyete Göre İncelenmesi

\begin{tabular}{llccccc}
\hline & Cinsiyet & n & Ort. & ss. & t & p \\
\hline Yabancı Uyruklu (Kaçak) İşçi Çalıştır- & Bayan & 75 & 2,91 &, 96 & 1,850 & 0,066 \\
manın Risk Olarak Algılanmaması & Bay & 144 & 2,64 & 1,04 & & \\
Yabancı Uyruklu (Kaçak) İşçi Çalıştır- & Bayan & 75 & 3,65 &, 85 & $-0,825$ & 0,410 \\
manın Dezavantajlı Görülmesi & Bay & 144 & 3,75 & 0,94 & & \\
Yabancı Uyruklu (Kaçak) İşçi Çalıştır- & Bayan & 75 & 3,66 &, 92 & 0,660 & 0,510 \\
manın Tehlike Olarak Görülmesi & Bay & 144 & 3,57 & 0,90 & & \\
Yabancı Uyruklu (Kaçak) İşçi Çalıştır- & Bayan & 75 & 2,45 & 1,08 & 1,217 & 0,225 \\
ma İle İlgili Olumlu Görüşler & Bay & 144 & 2,28 & 0,95 & & \\
Yabancı Uyruklu (Kaçak) İşçi Çalıştır- & Bayan & 75 & 3,53 &, 93 & 1,102 & 0,272 \\
manın Beyin Göçüne Etkisi & Bay & 144 & 3,38 & 0,96 & & \\
Yabancı Uyruklu (Kaçak) İşçi Çalıştır- & Bayan & 75 & 3,05 &, 98 & $-1,125$ & 0,262 \\
manın Küresel Katkısı & Bay & 144 & 3,21 & 1,03 & & \\
\hline
\end{tabular}

Yabancı uyruklu (kaçak) işçi çalıştırılmasına ilişkin çalışan görüşlerinin cinsiyete göre incelenmesinde, 6 faktöre ayırdığımız sorularımıza verilen yanıtlar sonucunda tüm faktörlerimizde anlamlı düzeyde farklılaşma olmadığı saptanmıştır ( $\mathrm{p}>0.05)$.

Bulgular sonucunda çalışanların, yabancı uyruklu (kaçak) işçi çalıştırmanın beyin göçüne etkisi olduğu görüşünün medeni duruma göre anlamlı düzeyde farklılaştığg saptanmıştır $(\mathrm{p}<0.05)$. Buna göre bekâr bireylerin yabancı uyruklu (kaçak) işçi çalıştırmanın beyin göçüne etkisi olduğu görüşüne katılma derecelerinin, evli bireylere göre daha yüksek olduğu görülmektedir. Yapılan sınamada diğer 5 faktörde medeni duruma göre anlamlı düzeyde bir farklılaşma gözlemlenmemiştir ( $p>0.05)$.

Bulgular sonucunda çalışanların, yabancı uyruklu (kaçak) işçi çalıştırmanın beyin göçüne etkisi olduğu görüşünün yaşa göre anlamlı düzeyde farklılaştığ 1 saptanmıştır $(p<0.05)$. Buna göre genç bireylerin yabancı uyruklu (kaçak) işçi çalıştırmanın beyin göçüne etkisi olduğu görüşüne katılma derecelerinin, yaşlı bireylere göre daha yüksek olduğu görülmektedir. Örneklem grubumuzu oluşturan kişilerin yaş aralığını diğer 5 faktöre göre sınadığımızda anlamlı düzeyde bir farklılaşma saptanmamıştır ( $\mathrm{p}>0.05)$. 
Tablo 6. Yabancı Uyruklu (Kaçak) İşçi Çalıştırmasına İlişkin Çalışan Görüşlerinin Medeni Duruma Göre İncelenmesi

\begin{tabular}{llccccc}
\hline & $\begin{array}{l}\text { Medeni } \\
\text { Durum }\end{array}$ & n & Ort. & ss. & t & p \\
\hline Yabancı Uyruklu (Kaçak) İşçi Çalıştır- & Bekar & 155 & 2,73 &, 95 & $-0,148$ & 0,882 \\
manın Risk Olarak Algılanmaması & Evli & 64 & 2,75 & 1,19 & & \\
\hline Yabancı Uyruklu (Kaçak) İşçi Çalıştır- & Bekar & 155 & 3,73 &, 93 & 0,307 & 0,759 \\
manın Dezavantajlı Görülmesi & Evli & 64 & 3,69 & 0,85 & & \\
\hline Yabancı Uyruklu (Kaçak) İşçi Çalıştır- & Bekar & 155 & 3,62 &, 96 & 0,392 & 0,695 \\
manın Tehlike Olarak Görülmesi & Evli & 64 & 3,57 & 0,77 & & \\
\hline Yabancı Uyruklu (Kaçak) İşçi Çalıştır- & Bekar & 155 & 2,32 & 1,02 & $-0,535$ & 0,593 \\
ma İle İlgili Olumlu Görüşler & Evli & 64 & 2,40 & 0,95 & & \\
\hline Yabancı Uyruklu (Kaçak) İşçi Çalıştır- & Bekar & 155 & 3,57 &, 94 & 3,336 & 0,001 \\
manın Beyin Göçüne Etkisi & Evli & 64 & 3,11 & 0,90 & & \\
\hline Yabancı Uyruklu (Kaçak) İşçi Çalıștır- & Bekar & 155 & 3,13 & 1,01 & $-0,472$ & 0,638 \\
manın Küresel Katkısı & Evli & 64 & 3,20 & 1,01 & & \\
\hline
\end{tabular}

Bulgular sonucunda çalışanların, yabancı uyruklu (kaçak) işçi çalıştırmanın çalışanlar için bir risk oluşturmadığı algısının eğitim durumuna göre anlamlı düzeyde farklılaştığ 1 saptanmıştır $(\mathrm{p}<0.05)$. Buna göre eğitim düzeyi lise ve ön lisans olan kişilerin yabancı uyruklu (kaçak) işçi çalıştırmanın çalışanlar için bir risk oluşturmadığı yönündeki algısının eğitim düzeyi lisans ve yüksek lisans olan kişilere kıyasla daha düşük olduğu görülmektedir.

Bulgular sonucunda çalışanların, yabancı uyruklu (kaçak) işçi çalıştırmanın çalışanlar ve çalışma sistemi için dezavantajlı olduğu görüşünün eğitim durumuna göre anlamlı düzeyde farklılaştığı saptanmıştır $(\mathrm{p}<0.05)$. Buna göre yüksek lisans mezunu kişilerin yabancı uyruklu (kaçak) işçi çalıştırmanın çalışanlar ve çalışma sistemi için dezavantajlı olduğu görüşüne diğer gruplara kıyasla daha fazla yakın olduğu görülmektedir.

Bulgular sonucunda çalışanların, yabancı uyruklu (kaçak) işçi çalıştırmanın çalışanlar için tehlike oluşturduğu algısının eğitim durumuna göre anlamlı düzeyde farklılaştığ saptanmıştır $(\mathrm{p}<0.05)$. Buna göre lise mezunu kişilerde yabancı uyruklu (kaçak) işçi çalıştırmanın çalışanlar için tehlike oluşturduğu görüşünün diğer gruplara kıyasla daha fazla hâkim olduğu görülmektedir.

Bulgular sonucunda çalışanların, yabancı uyruklu (kaçak) işçi çalıştırma ile ilgili olumlu görüş düzeylerinin, beyin göçüne etkisi olduğu görüşünün ve küresel katkısı olduğu görüşünün eğitim durumuna göre anlamlı düzeyde farklılaşmadığı saptanmıştır ( $p>0.05)$. 
Tablo 7. Yabancı Uyruklu (Kaçak) İşçi Çalıştırmasına İlişkin Çalışan Görüşlerinin Yaşa Göre İncelenmesi

\begin{tabular}{|c|c|c|c|c|c|c|}
\hline & Yaş & $\mathbf{n}$ & Ort. & ss. & $\mathbf{F}$ & $\mathbf{p}$ \\
\hline & $18-25$ & 81 & 2,65 & ,93 & 0,989 & 0,374 \\
\hline $\begin{array}{l}\text { Yabancı Uyruklu (Kaçak) İşçi } \\
\text { Çalıştırmanın Risk Olarak }\end{array}$ & $25-35$ & 92 & 2,85 & 1,05 & & \\
\hline Algılanmaması & $\begin{array}{l}35 \text { yaş ve } \\
\text { üzeri }\end{array}$ & 46 & 2,66 & 1,12 & & \\
\hline \multirow{3}{*}{$\begin{array}{l}\text { Yabancı Uyruklu (Kaçak) İşçi } \\
\text { Çalıştırmanın Dezavantajlı } \\
\text { Görülmesi }\end{array}$} & $18-25$ & 81 & 3,65 & ,97 & 1,705 & 0,184 \\
\hline & $25-35$ & 92 & 3,67 & 0,89 & & \\
\hline & $\begin{array}{l}35 \text { yaş ve } \\
\text { üzeri }\end{array}$ & 46 & 3,93 & 0,81 & & \\
\hline \multirow{3}{*}{$\begin{array}{l}\text { Yabancı Uyruklu (Kaçak) İşçi } \\
\text { Çalıştırmanın Tehlike Olarak } \\
\text { Görüilmesi }\end{array}$} & $18-25$ & 81 & 3,55 & 1,01 & 0,206 & 0,814 \\
\hline & $25-35$ & 92 & 3,64 & 0,89 & & \\
\hline & $\begin{array}{l}35 \text { yaş ve } \\
\text { üzeri }\end{array}$ & 46 & 3,63 & 0,75 & & \\
\hline \multirow{3}{*}{$\begin{array}{l}\text { Yabancı Uyruklu (Kaçak) İşçi } \\
\text { Çalıştırma İle İlgili Olumlu } \\
\text { Görüşler }\end{array}$} & $18-25$ & 81 & 2,42 & 1,12 & 0,412 & 0,663 \\
\hline & $25-35$ & 92 & 2,29 & 0,95 & & \\
\hline & $\begin{array}{l}35 \text { yaş ve } \\
\text { üzeri }\end{array}$ & 46 & 2,29 & 0,89 & & \\
\hline \multirow{3}{*}{$\begin{array}{l}\text { Yabancı Uyruklu (Kaçak) İşçi } \\
\text { Çalıştırmanın Beyin Göçüne Etkisi }\end{array}$} & $18-25$ & 81 & 3,52 & 1,01 & 4,773 & 0,009 \\
\hline & $25-35$ & 92 & 3,55 & 0,87 & & \\
\hline & $\begin{array}{l}35 \text { yaş ve } \\
\text { üzeri }\end{array}$ & 46 & 3,06 & 0,92 & & \\
\hline \multirow{3}{*}{$\begin{array}{l}\text { Yabancı Uyruklu (Kaçak) İşçi } \\
\text { Çalıştırmanın Küresel Katkısı }\end{array}$} & $18-25$ & 81 & 2,96 & 1,07 & 2,692 & 0,070 \\
\hline & $25-35$ & 92 & 3,21 & 0,97 & & \\
\hline & $\begin{array}{l}35 \text { yaş ve } \\
\text { üzeri }\end{array}$ & 46 & 3,37 & 0,95 & & \\
\hline
\end{tabular}


Tablo 8. Yabancı Uyruklu (Kaçak) İşçi Çalıştırmasına İlişkin Çalışan Görüşlerinin Eğitim Durumuna Göre İncelenmesi

\begin{tabular}{|c|c|c|c|c|c|c|}
\hline & Eğitim Durumu & $\mathbf{n}$ & Ort. & ss. & $\mathbf{F}$ & $\mathbf{p}$ \\
\hline \multirow{4}{*}{$\begin{array}{l}\text { Yabancı Uyruklu (Kaçak) İşçi } \\
\text { Çalıştırmanın Risk Olarak } \\
\text { Algılanmaması }\end{array}$} & Lise & 68 & 2,51 & 1,02 & 2,695 & 0,047 \\
\hline & Ön lisans & 50 & 2,63 &, 84 & & \\
\hline & Lisans & 75 & 2,92 & 1,09 & & \\
\hline & Yüksek Lisans & 26 & 2,98 & 1,04 & & \\
\hline \multirow{4}{*}{$\begin{array}{l}\text { Yabancı Uyruklu (Kaçak) İşçi } \\
\text { Çalıştırmanın Dezavantajlı } \\
\text { Görülmesi }\end{array}$} & Lise & 68 & 3,75 & 0,83 & 3,087 & 0,028 \\
\hline & Ön lisans & 50 & 3,58 & ,88 & & \\
\hline & Lisans & 75 & 3,62 & 1,03 & & \\
\hline & Yüksek Lisans & 26 & 4,18 & 0,62 & & \\
\hline \multirow{4}{*}{$\begin{array}{l}\text { Yabancı Uyruklu (Kaçak) İşçi } \\
\text { Çalıştırmanın Tehlike Olarak } \\
\text { Görüilmesi }\end{array}$} & Lise & 68 & 3,81 & 0,78 & 3,347 & 0,020 \\
\hline & Ön lisans & 50 & 3,29 & ,95 & & \\
\hline & Lisans & 75 & 3,59 & 0,98 & & \\
\hline & Yüksek Lisans & 26 & 3,71 & 0,77 & & \\
\hline \multirow{4}{*}{$\begin{array}{l}\text { Yabancı Uyruklu (Kaçak) İşçi } \\
\text { Çalıştırma İle İlgili Olumlu } \\
\text { Görüş̧ler }\end{array}$} & Lise & 68 & 2,42 & 1,00 & 0,258 & 0,855 \\
\hline & Ön lisans & 50 & 2,27 &, 84 & & \\
\hline & Lisans & 75 & 2,31 & 1,14 & & \\
\hline & Yüksek Lisans & 26 & 2,35 & 0,89 & & \\
\hline \multirow{4}{*}{$\begin{array}{l}\text { Yabancı Uyruklu (Kaçak) İşçi } \\
\text { Çalıştırmanın Beyin Göçüne } \\
\text { Etkisi }\end{array}$} & Lise & 68 & 3,35 & 0,93 & 0,553 & 0,647 \\
\hline & Ön lisans & 50 & 3,57 & ,94 & & \\
\hline & Lisans & 75 & 3,44 & 1,00 & & \\
\hline & Yüksek Lisans & 26 & 3,40 & 0,92 & & \\
\hline \multirow{4}{*}{$\begin{array}{l}\text { Yabancı Uyruklu (Kaçak) İşçi } \\
\text { Çalıştırmanın Küresel Katkısı }\end{array}$} & Lise & 68 & 3,09 & 1,03 & 1,780 & 0,152 \\
\hline & Ön lisans & 50 & 3,07 & ,94 & & \\
\hline & Lisans & 75 & 3,12 & 1,07 & & \\
\hline & Yüksek Lisans & 26 & 3,58 & 0,81 & & \\
\hline
\end{tabular}

Bulgular sonucunda çalışanların, yabancı uyruklu (kaçak) işçi çalıştırmanın beyin göçüne etkisi olduğu görüşünün meslekte çalışma süresine göre anlamlı düzeyde farklılaştığı saptanmıştır $(\mathrm{p}<0.05)$. Buna göre meslekte çalışma süresi daha kısa bireylerin yabanc1 uyruklu (kaçak) işçi çalıştırmanın beyin göçüne etkisi olduğu görüşüne katılma derecelerinin, meslekte çalışma süresi daha uzun olan bireylere göre daha yüksek olduğu görülmektedir.

Bulgular sonucunda çalışanların, yabancı uyruklu (kaçak) işçi çalıştırmanın küresel 
katkısı olduğu görüşünün meslekte çalışma süresine göre anlamlı düzeyde farklılaştığ1 saptanmıştır $(p<0.05)$. Buna göre meslekte çalışma süresi daha uzun bireylerin yabancı uyruklu (kaçak) işçi çalıştırmanın küresel katkısı olduğu görüşüne katılma derecelerinin, meslekte çalışma süresi daha kısa olan bireylere göre daha yüksek olduğu görülmektedir.

Diğer 4 faktörümüzü meslekte çalışma süresine göre incelediğimizde anlamlı düzeyde farklılaşma olmadığı gözlemlenmiştir ( $\mathrm{p}>0.05)$.

Tablo 9. Yabancı Uyruklu (Kaçak) İşçi Çalıştırmasına İlişkin Çalışan Görüşlerinin Meslekte Çalışma Süresine Göre İncelenmesi

\begin{tabular}{|c|c|c|c|c|c|c|}
\hline & $\begin{array}{c}\text { Meslekte } \\
\text { Çalışma Süresi }\end{array}$ & $\mathbf{n}$ & Ort. & ss. & $\mathbf{F}$ & $\mathbf{p}$ \\
\hline \multirow{3}{*}{$\begin{array}{l}\text { Yabancı Uyruklu (Kaçak) İşçi Ça- } \\
\text { lıştırmanın Risk Olarak Algılanma- } \\
\text { ması }\end{array}$} & $0-5$ yıl aras 1 & 77 & 2,77 & 1,03 & \multirow[t]{3}{*}{0,798} & \multirow[t]{3}{*}{0,451} \\
\hline & 5-10 y1l arası & 70 & 2,61 & ,97 & & \\
\hline & 10 yıl ve üzeri & 72 & 2,82 & 1,06 & & \\
\hline \multirow{3}{*}{$\begin{array}{l}\text { Yabancı Uyruklu (Kaçak) İşçi Çalış- } \\
\text { tırmanın Dezavantajlı Görülmesi }\end{array}$} & $0-5$ yıl aras 1 & 77 & 3,81 & 0,89 & \multirow[t]{3}{*}{0,651} & \multirow[t]{3}{*}{0,523} \\
\hline & 5-10 yil arası & 70 & 3,64 & ,95 & & \\
\hline & 10 yıl ve üzeri & 72 & 3,69 & 0,89 & & \\
\hline \multirow{3}{*}{$\begin{array}{l}\text { Yabancı Uyruklu (Kaçak) İşçi Çalış- } \\
\text { tırmanın Tehlike Olarak Görülmesi }\end{array}$} & $0-5$ yil aras 1 & 77 & 3,69 & 0,89 & \multirow[t]{3}{*}{0,702} & \multirow[t]{3}{*}{0,497} \\
\hline & 5-10 y1l arası & 70 & 3,51 & 1,02 & & \\
\hline & 10 yıl ve üzeri & 72 & 3,60 & 0,80 & & \\
\hline \multirow{3}{*}{$\begin{array}{l}\text { Yabancı Uyruklu (Kaçak) İşçi Çalış- } \\
\text { tırma İle İlgili Olumlu Görüşler }\end{array}$} & $0-5$ yıl arası & 77 & 2,28 & 1,01 & \multirow[t]{3}{*}{1,239} & \multirow[t]{3}{*}{0,292} \\
\hline & 5-10 yil arası & 70 & 2,25 & 1,05 & & \\
\hline & 10 yıl ve üzeri & 72 & 2,49 & 0,95 & & \\
\hline \multirow{3}{*}{$\begin{array}{l}\text { Yabancı Uyruklu (Kaçak) İşçi Çalış- } \\
\text { tırmanın Beyin Göçüne Etkisi }\end{array}$} & 0-5 yıl arası & 77 & 3,68 & 0,88 & \multirow[t]{3}{*}{9,512} & \multirow[t]{3}{*}{0,000} \\
\hline & 5-10 yil arası & 70 & 3,56 & ,95 & & \\
\hline & 10 yıl ve üzeri & 72 & 3,06 & 0,92 & & \\
\hline \multirow{3}{*}{$\begin{array}{l}\text { Yabancı Uyruklu (Kaçak) İşçi Çalış- } \\
\text { tırmanın Küresel Katkısı }\end{array}$} & $0-5$ yıl arası & 77 & 3,00 & 1,08 & \multirow[t]{3}{*}{2,655} & \multirow[t]{3}{*}{0,073} \\
\hline & 5-10 y1l arası & 70 & 3,10 & ,97 & & \\
\hline & 10 yıl ve üzeri & 72 & 3,37 & 0,95 & & \\
\hline
\end{tabular}

Bulgular sonucunda çalışanların, yabancı uyruklu (kaçak) işçi çalıştırmanın beyin göçüne etkisi olduğu görüşünün bulunduğu kurumda çalışma süresine göre anlamlı düzeyde farklılaştığı saptanmıştır ( $\mathrm{p}<0.05)$. Buna göre bulunduğu kurumda çalışma süresi 0-5 yıl arası olan bireylerin yabancı uyruklu (kaçak) işçi çalıştırmanın beyin göçüne etkisi olduğu görüşüne katılma derecelerinin, 5 yıl ve üzeri olan bireylere göre daha yüksek olduğu görülmektedir. Bulunduğu kurumda çalışma süresi arttıkça yabancı uyruklu (kaçak) işçi çalıştırılmasının beyin göçüne etkisi olduğu görüşünde düşme yaşanmaktadır. 
Bulgular sonucunda çalışanların, yabancı uyruklu (kaçak) işçi çalıştırmanın tehlike olarak görülmesi görüşünün bulunduğu kurumda çalışma süresine göre anlamlı düzeyde farklılaştığı saptanmıştır ( $\mathrm{p}<0.05)$. Buna göre bulunduğu kurumda çalışma süresi 0-5 yıl arası olan bireylerin yabancı uyruklu (kaçak) işçi çalıştırmanın tehlike olarak görülmesi katılma derecelerinin, 5 yıl ve üzeri olan bireylere göre daha yüksek olduğu görülmektedir. Bulunduğu kurumda çalışma süresi arttıkça yabancı uyruklu (kaçak) işçi çalıştırılmasının beyin göçüne etkisi olduğu görüşünde düşme yaşanmaktadır.

Diğer 4 faktöre göre bulunduğu kurumda çalışma süresi sınandığında anlamlı düzeyde farklılaşma saptanmamıştır ( $\mathrm{p}>0.05)$.

Tablo 10. Yabancı Uyruklu (Kaçak) İşçi Çalıştırmasına İlişkin Çalışan Görüşlerinin Bulunulan Kurumda Çalışma Süresine Göre İncelenmesi

\begin{tabular}{|c|c|c|c|c|c|c|}
\hline & $\begin{array}{c}\text { Bulunulan } \\
\text { Kurumda } \\
\text { Çalışma } \\
\text { Süresi }\end{array}$ & n & Ort. & ss. & $\mathbf{t}$ & p \\
\hline $\begin{array}{l}\text { Yabancı Uyruklu (Kaçak) İşçi } \\
\text { Çalıştırmanın Risk Olarak Algı- } \\
\text { lanmaması }\end{array}$ & $\begin{array}{l}0-5 \text { yıl arası } \\
5 \text { yıl ve üzeri }\end{array}$ & $\begin{array}{l}116 \\
103\end{array}$ & $\begin{array}{l}2,73 \\
2,74\end{array}$ & $\begin{array}{l}1,00 \\
1,05\end{array}$ & $-0,052$ & 0,958 \\
\hline $\begin{array}{l}\text { Yabancı Uyruklu (Kaçak) İşçi } \\
\text { Çalıştırmanın Dezavantajlı Gö- } \\
\text { rülmesi }\end{array}$ & $\begin{array}{l}0-5 \text { yıl arası } \\
5 \text { yıl ve üzeri }\end{array}$ & $\begin{array}{l}116 \\
103\end{array}$ & $\begin{array}{l}3,76 \\
3,67\end{array}$ & $\begin{array}{l}0,91 \\
0,91\end{array}$ & 0,758 & 0,449 \\
\hline $\begin{array}{l}\text { Yabancı Uyruklu (Kaçak) İşçi } \\
\text { Çalıştırmanın Tehlike Olarak } \\
\text { Görülmesi }\end{array}$ & $\begin{array}{l}0-5 \text { yıl arası } \\
5 \text { yıl ve üzeri }\end{array}$ & $\begin{array}{l}116 \\
103\end{array}$ & $\begin{array}{l}3,70 \\
3,50\end{array}$ & $\begin{array}{l}0,95 \\
0,84\end{array}$ & 1,604 & 0,110 \\
\hline $\begin{array}{l}\text { Yabancı Uyruklu (Kaçak) İşçi } \\
\text { Çalıştırma İle İlgili Olumlu Gö- } \\
\text { rüşler }\end{array}$ & $\begin{array}{l}0-5 \text { yıl arası } \\
5 \text { yıl ve üzeri }\end{array}$ & $\begin{array}{l}116 \\
103\end{array}$ & $\begin{array}{l}2,37 \\
2,31\end{array}$ & $\begin{array}{l}1,07 \\
0,92\end{array}$ & 0,445 & 0,657 \\
\hline $\begin{array}{l}\text { Yabancı Uyruklu (Kaçak) İşçi Ça- } \\
\text { lıştırmanın Beyin Göçüne Etkisi }\end{array}$ & $\begin{array}{l}0-5 \text { yıl arası } \\
5 \text { yıl ve üzeri }\end{array}$ & $\begin{array}{l}116 \\
103\end{array}$ & $\begin{array}{l}3,56 \\
3,29\end{array}$ & $\begin{array}{l}0,91 \\
0,97\end{array}$ & 2,082 & 0,039 \\
\hline $\begin{array}{l}\text { Yabancı Uyruklu (Kaçak) İşçi } \\
\text { Çalıştırmanın Küresel Katkısı }\end{array}$ & $\begin{array}{l}0-5 \text { yıl arası } \\
5 \text { yıl ve üzeri }\end{array}$ & $\begin{array}{l}116 \\
103\end{array}$ & $\begin{array}{l}3,04 \\
3,28\end{array}$ & $\begin{array}{l}1,03 \\
0,97\end{array}$ & $-1,717$ & 0,087 \\
\hline
\end{tabular}

\section{SONUÇ}

$\mathrm{Bu}$ araştırmada yabancı işçi çalıştırılmasının çalışan kesime etkisini ve KOBİ'lerin veya işverenlerin yabancı işçi tercihine çalışan kesimin bakış açısını ve bu durumlara karşı düşüncelerinin ne olduğu incelenmiştir.

Bulgulara göre çalışanların genel olarak yabancı uyruklu (kaçak) işçi çalıştırmanın küresel 
katkısı olup olmaması üzerinde görüşü kararsız yöndedir. Araştırmada çalışanların, yabancı uyruklu (kaçak) işçi çalıştırmanın küresel katkısı olduğuna ilişkin görüşlere katılma derecesinin cinsiyete, medeni duruma, yaşa, eğitim durumuna, çalışma süresine ve şu anki kurumda çalışma süresine göre anlamlı bir farklılık göstermediği saptanmıştır. $\mathrm{Bu}$ sebeple çalışanların genel olarak yabancı uyruklu (kaçak) işçi çalıştırmanın küresel katkısı olup olmaması ile ilgili kararsız olması tüm gruplarda benzerlik göstermektedir.

Analizler neticesinde çalışanların genel olarak yabancı uyruklu (kaçak) işçi çalıştırma ile ilgili olumlu görüşlere katılmadığı belirlenmiştir. Bulgular sonucunda çalışanların, yabancı uyruklu (kaçak) işçi çalıştırma ile ilgili olumlu görüş düzeylerinin cinsiyete, medeni duruma, yaşa, eğitim durumuna, çalışma süresine ve şu anki kurumda çalışma süresine göre anlamlı bir farklılık göstermediği saptanmıştır. Buna göre çalışan kesimin yabancı uyruklu (kaçak) işçi çalıştırma ile ilgili olumlu ifadelere katılmaması tüm gruplarda benzerlik göstermektedir.

Araştırma kapsamında elde edilen bulgulara göre çalışanların, yabancı uyruklu (kaçak) işçi çalıştırmanın çalışanlar için bir risk oluşturmadığı algısının cinsiyete, medeni duruma, yaşa, meslekte çalışma süresine ve şu anki kurumda çalışma süresine göre farklılık göstermezken; eğitim durumuna göre farklılaştığı tespit edilmiştir. Buna göre eğitim düzeyi lise ve ön lisans olan kişilerin yabancı uyruklu (kaçak) işçi çalıştırmanın çalışanlar için bir risk oluşturmadığı yönündeki algısının eğitim düzeyi lisans ve yüksek lisans olan kişilere kıyasla daha düşük olduğu belirlenmiştir. Yabancı uyruklu (kaçak) işçi çalıştırılmasının, çalışanlar için bir risk oluşturduğu görüşü ile ilgili genel katılma derecesi incelendiğinde ortalama kararsızlığı işaret etmektedir. Yani konu ile ilgili kesin olumlu veya olumsuz görüş hâkim değildir.

Araştırma kapsamında elde edilen bulgulara göre yabancı uyruklu (kaçak) işçi çalıştırmanın çalışanlar ve çalışma sistemi için dezavantajlı olduğu görüşü cinsiyete, medeni duruma, yaşa, meslekte çalışma süresine ve şu anki kurumda çalışma süresine göre farklılık göstermezken; eğitim durumuna göre farklılaştığ 1 tespit edilmiştir. Buna göre yüksek lisans mezunu kişiler arasında yabancı uyruklu (kaçak) işçi çalıştırmanın çalışanlar ve çalışma sistemi için dezavantajlı olduğu görüşü diğer gruplara kıyasla daha fazla hâkimdir. Genel değerlendirmeler sonucunda elde edilen bulgulara göre çalışanlar tarafından yabancı uyruklu (kaçak) işçi çalıştırılması, çalışan kesim için dezavantajlı görülmektedir.

Çalışmada elde edilen bir diğer bulguya göre yabancı uyruklu (kaçak) işçi çalıştırmanın çalışanlar için tehlike oluşturduğu algısının cinsiyete, medeni duruma, yaşa, meslekte çalışma süresine ve şu anki kurumda çalışma süresine göre farklılık göstermezken; eğitim durumuna göre farklılaştı̆̆ 1 tespit edilmiştir. Buna göre lise mezunu kişilerde yabancı uyruklu (kaçak) işçi çalıştırmanın çalışanlar için tehlike oluşturduğu görüşünün diğer gruplara kıyasla daha fazla hâkim olduğu belirlenmiştir. Genel ortalamalara göre çalışanlar tarafından yabancı uyruklu (kaçak) işçi çalıştırılması, çalışan kesim için tehlike olarak görüldüğü tespit edilmiştir. 
Araştırma bulguları yabancı uyruklu (kaçak) işçi çalıştırmanın beyin göçüne etkisi olduğu görüşü üzerinde çalışan kesimin kendi aralarında çeşitli demografik bilgiler bazında farklı eğilimlere sahip olduğu hipotezini desteklemektedir. Buna göre konu üzerindeki görüşün cinsiyete ve eğitim durumuna farklılık göstermezken; medeni duruma, yaşa, meslekte çalışma süresine ve bulunduğu kurumda çalışma süresine göre farklılaştığı tespit edilmiştir. Buna göre bekâr bireylerin yabancı uyruklu (kaçak) işçi çalıştırmanın beyin göçüne etkisi olduğu görüşüne katılma derecelerinin, evli bireylere göre daha yüksek olduğu saptanmıştır. Buna ek olarak bireylerin yabancı uyruklu (kaçak) işçi çalıştırmanın beyin göçüne etkisi olduğu görüşüne katılma derecelerinin, yaşlı bireylere göre daha yüksek olduğu gözlenmiştir. Ayrıca meslekte çalışma süresi ve şu anki kurumda çalışma süresi daha kısa bireylerin yabancı uyruklu (kaçak) işçi çalıştırmanın beyin göçüne etkisi olduğu görüşüne katılma derecelerinin, meslekte çalışma süresi ve bulunduğu kurumda çalışma süresi daha uzun olan bireylere göre daha yüksek olduğu tespit edilmiştir. Çalışan kesimin genel görüşü değerlendirildiğinde ise yabancı uyruklu (kaçak) işçi çalıştırmanın beyin göçüne etkisi olduğu görüşüne katıldıkları saptanmıştır. 


\section{KAYNAKÇA}

Deniz, T. (2014). Uluslararası Göç Sorunu Perspektifinde Türkiye. Türkiye Sosyal Araştırmalar Dergisi, cilt 18, sayı.1, s. 175-204

Asar, A. (2007). Türk Yabancılar Mevzuatında Yabancı Ve Hakları. Ankara.

Aydınoğlu, R. (2006). 1990 Sonrası Türkiye’de Yabancı Kaçak İşçilik Olgusu Ve Çözüm Yolları. Ankara: Yüksek Lisans Tezi, Ankara Üniversitesi.

Candan, M. (2007). Kayıt Dışı İstihdam, Yabancı Kaçak İşçi İstihdamı Ve Toplumumuz Üzerine Sosyolojik Etkileri. Ankara: Yüksek Lisans Tezi, Ankara Üniversitesi.

Çağrı, E. (2003). Küreselleşme Döneminin Tehditleriyle Mücadele. Politika Dergisi, 1303, s.4-8.

ÇSGB (2013). Yabancılara İlişkin Online Çalışma İzni Başvurusunun Yapılması. Çalışma Ve Sosyal Güvenlik Bakanlığı: http://www.csgb.gov.tr/

T.C. Dışişleri Bakanlığı, (2013). Türkiye’nin Yasadışı Göçle Mücadelesi. Dışişleri Bakanlığı: http://www.mfa.gov.tr/

DPT (2014). DPT’nin Kayıt dışı İstihdam Ve Yabancı Kaçak İşçi İstihdamı Sorununa Bakışı; Kayıt dışı İstihdam Ve Yabancı Kaçak İşçi İstihdamı. Ankara: Çalışma Ve Sosyal Güvenlik Bakanlığı.

Duymaz, İ. (1995). Türkiye’de Yabancı Kaçak İşçilik. İstanbul: Friedrich Ebert Vakfı.

Everett S. Lee, “A Theory of Migration,” in Migration, ed. J.A. Jackson, London: Cambridge University Press, 1969, s. 285-286

FACTFISH, http://www.factfish.com/

İçduydgu, A., Sert, D. ve Karaçay, A. B. (2009). Türkiye’ye Yönelen Göç ve Sığınma Hareketleri ve Politikaları Üzerine . İstanbul: MireKoç.

İSMMMO (2011). Yabancı Kaçak İşçiler Ve Türkiye’ye Göç Hareketi. İstanbul: İstanbul Muhasebeciler Mali Müşavirler Odası Yayınları.

Karasar, N., 2005. Bilimsel araştırma yöntemi. Ankara: Nobel Yayınları.

Karluk, R. (1996). Türkiye Ekonomisi Tarihsel Gelişimi Yapısal Ve Sosyal Değişim. İstanbul.

Koç, Y. (2000). Kaçak İşçilikle Mücadele Sorunlar Ve Öneriler. Türk-İş Eğitim Yayınları , s.24.Lordoğlu, K. (2002). Türkiye'de Yabancıların Kaçak Çalışmaları ve Bağlantılı Sorunlar Üzerine Bir Tartışma. TÜHİS Dergisi, Cilt: 18, Sayı:6, s. 31-37.

Lordoğlu, K. (2004). Türkiye'de Yabancıların Kaçak Çalışması ve Bu Çalışmaya İlişkin Bir Araştırma. Mimoza-Marmara.

Özkanlı, Ö. ve Oncer, M. (1998). Ülkemiz İşletmelerinde Üretim Maliyetlerini Düşürme Amaçlı Çalışmaların Uygulanma Düzeyi. Ankara Üniversitesi SBF Dergisi, Cilt 53, 
Say1 1, s.232-249.

Sennet, R. (2013). Karakter Aşınması. çev. Barış Yıldırım, 12. Basım, İstanbul: Ayrıntı Yayınevi.

Şimşek, B. (2000). İş gücü Piyasalarının Küreselleşmesi ve Küresel İş gücü Piyasasında Ulusal İş gücü Piyasalarının Yeri. İş Güç Endüstri İlişkileri İnsan Kaynakları Dergisi, Cilt 2, Sayı 1, Sira 3.

Tezel, A. (2013, Nisan 04). Yabancı Kaçak İşçi Çalıştırmak Yanlış. Habertürk: http:// www.haberturk.com/yazarlar/ali-tezel-1016/833147-yabanci-kacak-isci-calistirmakyanlis

Toksöz, G., Erdoğdu, S. ve Kaşka, S. (2012). Türkiye'de Düzensiz Emek Göçü ve Göçmenlerin Emek Piyasasındaki Durumları. İstanbul: İsveç Uluslararası Kalkınma ve İş birliği Ajansı.

Toptaş, Ü. (1998). Türkiye'de Kayıt dışı Ekonominin Nedenleri. Ankara: Tes-Ar Yayınları.

UNHCR (2013). Mültecilerin Yaş, Cinsiyet ve Ülke Dağ1lımı İstatistikleri. http://www. unhcr.org/turkey/home.php

Zaim, S. (1993). Çalışma Ekonomisi. İstanbul: Filiz Yayınevi.

\section{YASALAR}

2007 sayılı “Türkiye'deki Türk Vatandaşlarına Tahsis Edilen Sanat ve Hizmetler Hakkında Kanun, 11.6.1932

4817 Sayılı Yabancıların Çalışma İzinleri Hakkında Kanun, T.C. Resmi Gazete, 25040, 16.03.2003

5683 Sayılı Yabancıların Türkiye'de İkamet Ve Seyahatleri Hakkında Kanun, T.C Resmi Gazete, 7564, 24.07.1950 